\title{
RADICAL TPACIFR
} A SOCIALIST, FEMINIST, AND ANTI-RACIST JOURNAL ON THE THEORY AND PRACTICE OF TEACHING

Contributors' Notes Radicalizing the Liberal Arts

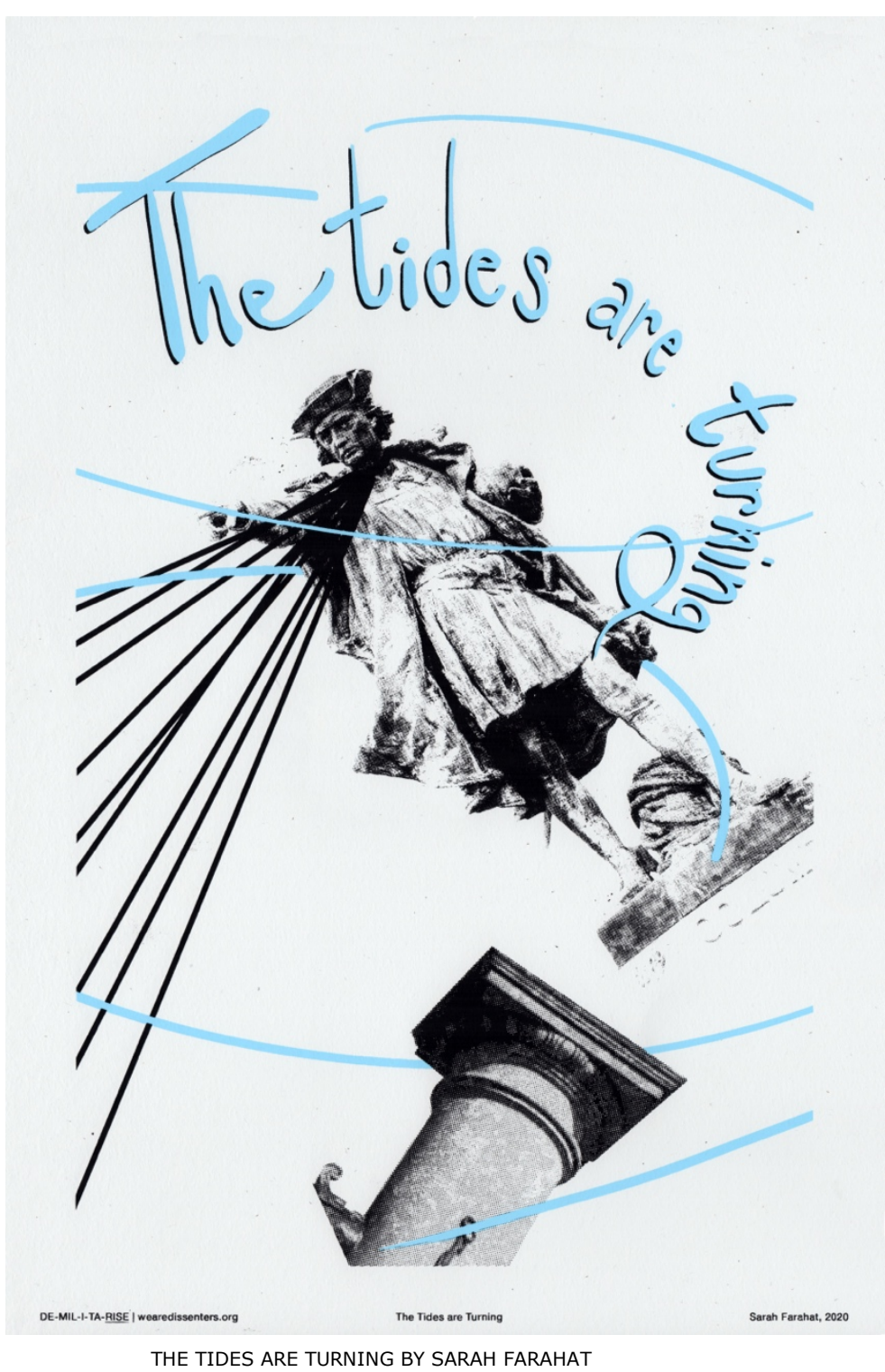


Zakiya R. Adair is an assistant professor jointly appointed in the departments of African American Studies and Women's Gender and Sexuality Studies at The College of New Jersey. She earned a Doctorate in Women's Studies at the University of Washington.

Betsy J. Bannier earned her Ph.D. in adult \& continuing education with an emphasis in online chemistry education at University of Wisconsin - Milwaukee and earned her M.S. in analytical chemistry at University of North Dakota. She is a tenured Professor of Chemistry at Lake Region State College.

Bennett Brazelton is a history teacher and independent writer in Boston. His research focuses on education, Black studies, and anticolonial thought and history. His work is accepted, forthcoming, or published in Philosophy and Global Affairs, cultural geographies, Fire!!!, and Radical Americas.

Ernie Brill writes fiction and poetry about everyday people. His collection I Looked Over Jordan and Other Stories explores race and class among hospital workers. Mr. Brill received his BA and MA in English from San Francisco State University.

Vanessa Cepeda is an Associate Product Manager at CareMessage, the largest patient engagement platform for underserved populations that reaches over 10 million patients nationwide. She's a first-generation college graduate (Geneseo '19) from The Bronx, New York and is currently living in Denver, Colorado.

Robin P. Chapdelaine is an Assistant Professor of African and Women's and Gender history at Duquesne University. Her research and teaching focuses modern Africa, gender, human trafficking, and child labor. Her recently published book, The Persistence of Slavery: An Economic History of Child Trafficking in Nigeria, is \# 17 out of the top 40 bestselling African history books (Library Journal).

Sarah E. Chinn teaches English at Hunter College, CUNY. A member of the Radical Teacher editorial collective, she's the author of three books, Technology and the Logic of American Racism: A Cultural History of the Body as Evidence (2000), Inventing Modern Adolescence: The Children of Immigrants in Turn-of-the-Century America (2009), and Spectacular Men: Race, Gender, and Nation on the Early American Stage (2017), as well as articles in Signs, GLQ, Prospects, American Quarterly, and WSQ.

Jillian Crocker is Assistant Professor of Sociology at SUNY Old Westbury, a public liberal arts college on Long Island, NY guided by long-standing commitments to expanding access to liberal education and to building a more just and sustainable world.

In his 31 years as a NYC high school English teacher, Todd Friedman fought three major battles against the Department of Education. Todd's poems have been published in English Journal, The Brooklyn Eagle, Haight Ashbury Literary Journal, Jewish Currents, and Tikkun.

Sabrina González (she/her) is a PhD candidate in the Department of History at University of Maryland. She graduated from Universidad Nacional de La Matanza, Buenos
Aires, Argentina, with a BA in social communication. Her dissertation entitled: "Schools as Laboratories: Science, Children's Bodies, and School Reformers in the Making of Modern Argentina (1880-1930)" studies the historical processes by which school teachers in South America used education as a tool for emancipation and built a transnational school reform movement that both challenged and contributed to children's disciplining.

Bruce Gorden is a native San Diegan and life-long surfer. He Is a veteran, having served in the USAF. He began writing poetry as a way of coping with war and graduate school. He recently won a chap book contest and the book, The Long Good-bye, is available at ProlificPress.com.

Jaira J. Harrington is an assistant professor of Black Studies at the University of Illinois Chicago. Her teaching and scholarship are inspired by political activism, Black feminism, and the global Black diaspora in the Américas. Her current research focuses on the intersection of race, labor, and gender among union-affiliated paid household domestic workers in Brazil.

Victoria M. Huỳnh is a diasporic writer and aspiring educator. She recently finished her undergraduate studies at Soka University of America, where she was a student organizer for Critical Global Ethnic Studies. She studies Marxism and feminism in the Third World and wants to see the end of U.S. imperialism, its femicide(s), and its wars.

Meghan Kwast is head of collection management services at Pearson Library at California Lutheran University.

Jolivette Mecenas, associate professor of English, directs first-year writing at California Lutheran University.

Professor $\mathbf{X}$ is a faculty member at Soka University of America.

Aneil Rallin (they/them) is associate professor of rhetoric and composition and director of the writing program at Soka University of America, situated on the lands of the Acjachemen peoples, and author of Dreads and Open Mouths: Living/Teaching/Writing Queerly.

robbie (routenberg) serves as Chief Diversity Officer (CDO) at their alma mater, SUNY Geneseo, and national consultant with InciteChange! Consulting, L.L.C. As a scholarpractitioner, robbie's focus has included intergroup dialogue, social justice theatre, facilitation training, and other modes of social justice education.

Heather Moore Roberson is Assistant Professor of Community and Justice Studies at Allegheny College in Meadville, PA.

Alice Rutkowski is an Associate Professor and Chair of English at SUNY Geneseo, where she also coordinates the campus Safe Zone program and mentors student leaders. She teaches and writes about women writers, race, and the Civil War and Reconstruction; and queer theory and trans politics.

John Schlueter teaches English and composition at Saint Paul College. His writing and research interests include 
higher education reform, pedagogy, and $19^{\text {th }}$ century American literature.

Jordyn Solidum-Saito has been an educator, organizer, and policy analyst. She is a recent graduate of Soka University of America, where she was a student organizer. She has played an active role in campus movements to destabilize academia as a point of imperialist proliferation. Currently based in Madrid, Spain, she is a cultural producer focused on uplifting the status of Filipina migrant domestic workers in Spain.

Cara K. Snyder (she/they) is Assistant Professor of Women's, Gender, and Sexuality Studies at the University of Louisville. They have also taught courses at Federal and State Universities in Bahía and Pernambuco, Brazil. Snyder earned a Ph.D. from the Harriet Tubman Department of Women's, Gender, and Sexuality Studies, with certificates in Teaching and Learning and Digital Studies, at the University of Maryland, College Park. Their research interests include transnational feminism, Latin American/Brazilian Studies, physical cultural/sport studies, and digital studies.

Kristen Michala Storms is a radical Black feminist scholar and co-creator/former organizer of Critical Global Ethnic Studies at her undergraduate institution Soka University of America. Currently, she is a J.D. candidate at Loyola Law School in Los Angeles to pursue grass-roots, communitybased legal justice advocacy for BIPOC communities domestically and abroad.

Megan Toomer is a second-year law student at Emory University School of Law and is studying to become a criminal defense attorney. She has worked with organizations including the Southern Center for Human Rights, Family Equality Council, the International Refugee Assistance Project, the Petey Greene Program, and Jewish Family and Community Services.

Lance $\mathbf{C}$. Thurner is Adjunct Professor of History at Rutgers University, Newark and is a historian of science and medicine in Latin America and the US/Mexican borderlands. He is committed to pushing the boundaries of the digital humanities to achieving anti-racist, feminist, and decolonial pedagogical goals. His pedagogical projects and students' work can be found at www.empiresprogeny.org and www.statesofbelonging.org.

Yvonne Wilber is the head of undergraduate instruction and outreach at Pearson Library at California Lutheran University.

Richie Zweigenhaft, Charles A. Dana Professor of Psychology, Emeritus, at Guilford College, is the co-author (with G. William Domhoff) of three books on the American power elite and is the co-editor (with Gene Borgida) of Collaboration in Psychological Science. His most recent book is titled Jews, Palestinians, and Friends: 45 Years at a Quaker College. 